\title{
PETA PERSEPSI KONSUMEN TERHADAP ATRIBUT RUMAH TINGGAL DI SURABAYA
}

\author{
Njo Anastasia \\ Program Manajemen Keuangan, Fakultas Ekonomi, Universitas Kristen Petra Surabaya \\ Email: anas@peter.petra.ac.id
}

\begin{abstract}
Abstrak
Penelitian ini bertujuan untuk melakukan pemetaan persepsi konsumen terhadap atribut-atribut rumah tinggal yang diminati, yaitu: lingkungan, lokasi, harga dan fisik. Penelitian ini merupakan penelitian deskriptif yang datanya diperoleh melalui penyebaran kuesioner kepada sejumlah sampel 384 orang di beberapa perumahan di wilayah Surabaya Timur dan Surabaya Barat.Hasil penelitian menunjukkan bahwa konsumen memprioritaskan atribut lingkungan, yaitu: fasilitas umum (air, listrik, telepon) dan fasilitas sosial (pasar, sarana transportasi, tempat ibadah). Atribut lokasi yang paling diprioritaskan adalah jarak tempuh ke sekolah dan pasar tradisional.
\end{abstract}

Kata kunci: Peta persepsi, atribut lingkungan, atribut lokasi, atribut harga, atribut fisik.

\begin{abstract}
This study aimed to map consumer perceptions of residential attributes, namely the neighbourhood, location, price, and physical. The research method was descriptive that data obtained through questionnaires to sample number of 384 respondents in some residential estate of East and West Surabaya. The results showed that consumers prioritize neighbourhood attributes of public facilities (water, electricity, telephone) and social amenities (markets, transportation, places of worship). The most priority of location was the distance to school and traditional markets.
\end{abstract}

Keywords: Map perception, neighbourhood attributes, location attributes, price attributes, physical attributes.

\section{PENDAHULUAN}

Deputi Kepala Perwakilan Bank Indonesia Wilayah IV, Sarwanto menjabarkan bahwa pertumbuhan ekonomi di Jawa Timur pada Triwulan II/2012 mencapai 7,21\% lebih tinggi dibandingkan periode yang sama tahun lalu, bahkan lebih tinggi daripada pertumbuhan ekonomi nasional yang hanya 6,40\%. Pertumbuhan ini berlanjut pada Triwulan III/2012, yaitu sebesar 7,29\% (Prajayanti, 2013). Menurut Yahya (2012), pertumbuhan properti selaras dengan prediksi nasional yang juga menunjukkan pertumbuhan positif dengan rata-rata sebesar $12 \%$ $20 \%$ sepanjang akhir tahun 2012. Khusus untuk kota besar seperti Jakarta, Surabaya dan Medan, pertumbuhan sektor properti dapat mencapai di atas $15 \%$. Indikator utama sektor properti adalah Nilai Jual Obyek Pajak (NJOP) harga tanah yang setiap tahun secara rata-rata naik antara $10 \%-17 \%$, bahkan untuk lokasi di jalan utama dapat meningkat $20 \%$. Berdasarkan perkembangan tersebut, maka tidak mengherankan apabila properti merupakan alternatif pilihan berinvestasi yang sangat menarik.
Kecenderungan (trend) investasi yang positif serta kebutuhan pokok setiap orang akanrumah tinggal akan menciptakan peluang bagi pengembang (developer). Pengembang berusaha membangun rumah tinggal dalam areal perumahan dengan mempertimbangkan berbagai faktor, yaitu faktor lingkungan, lokasi, harga dan fisik. Rumah tinggal yang dibangun pengembang akanselalu disesuaikan dengan segmen kelas ekonomi, yaitu perumahan kelas atas, kelas menengah dan kelas bawah (Rahardian, 2003). Segmentasi konsumen akan menciptakan stimuli sehingga timbul persepsi pada benak konsumen akan produk-produk rumah tinggal yang dikembangkan tersebut.

Faktor lingkungan merupakan salah satu faktor yang dipertimbangkan konsumen sebelum membeli rumah. Lingkungan perumahan yang diaplikasikan pada umumnya menggunakan model cluster atau grid. Gaya atau trend arsitektur menekankan pada gaya etnik, gaya mediterania, romawi, atau minimalis. Dengan adanya pembangunan infrastruktur yang lengkap di kawasan perumahan tersebut, diharapkan penghuni tidak hanya sekadar menikmati rumah sebagai tempat istirahat, tetapi juga sekaligus dapat 
merasakan kenyamanan lingkungan perumahan yang asri dan menawan. (Sanda, 2003).

Salah satu perumahan dengan lingkungan yang lengkap adalah Perumahan CitraRaya yang dikembangkan oleh Ciputra Groupdi Surabaya Barat. Kawasan tersebut dibangun dengan konsep Singapuranya kota Surabaya dengan mengusung tema bersih, hijau, dan modern dilengkapi kawasan wisata keluarga yang lengkap dan modern, kawasan komersial, sekolah dan tempat ibadah, serta padang golf berstandar internasional (Cahyono, 2008). Hal ini juga terjadi pada pengembangan perumahan yang dilakukan oleh perusahaan pengembang lainnya seperti Pakuwon Grup, Intiland, dan beberapa perusahaan pengembang lain.

Di sisi lain, pihak konsumen sebelum membeli rumah biasanya juga akan memperhatikan faktor lokasi, terkait dengan kemudahan aksesbilitas untuk menjangkau suatu lokasi lain dari tempat tinggal, seperti tempat kerja, sekolah, pasar, tempat rekreasi maupun tempat ibadah. Jika jangkauan area yang hendak dicapai terlalu jauh akan mengakibatkan biaya operasional setiap bulan menjadi semakin tinggi, demikian pula sebaliknya. Akibatnya meskipun harga rumah yang dibeli terkesan murah, tetapi apabila lokasinya terlalu jauh maka akan membuat konsumen memiliki tingkat biaya hidup setiap bulan yang tinggi.

Atribut fisik yang ditawarkan pengembang antara lain terkait dengan rancang bangunan atau layout bangunan, mutu bahan bangunan yang digunakan dalam pembuatan rumah tinggal tersebut termasuk luas tanah dan luas bangunan, serta pemandangan yang ditawarkan. Pengembang akan berusaha menciptakan atribut fisik sebaik mungkin untuk menarik minat konsumen, tetapi semakin bagus atribut fisik yang ditawarkan maka harga yang ditawarkan pada konsumen juga semakin tinggi.

Faktor harga menjadi salah satu faktor utama konsumen sebelum memutuskan membeli rumah, sebab terkait dengan cara pembayarannya baik secara tunai atau kredit dan besarnya diskon atau hadiah yang ditawarkan pengembang (Primananda, 2010). Konsumen akan membandingkan harga rumahrumah yang ditawarkan menurut kebutuhan dan kemampuannya. Akan tetapi, saat sebelum melakukan pembayaran, konsumen biasanya juga mempertimbangkan cadangan dana untuk biaya lain-lain, seperti biaya jaminan, biaya provisi, pajakdan notaris.

Sirgy, Grzeskowiak dan Su (2005) dalam teori self-congruitymenjelaskan adanya keterkaitan antara aspek fungsional lingkungan rumah,gambaran tentang penghuni perumahan, kepribadian pembeli rumah, preferensi konsumen dengan atribut perumahan dan pilihannya, serta aspek mobilitas/ migrasi pada perumahan dengan faktor-faktor motivasi pada pembelian rumah, pembentukan preferensi konsumen serta keputusan pembelian rumah. Dari perspektif pengembang yang terlibat dalam persaingan pasar properti, mereka akan berusaha untuk menarik minat pembeli dengan melakukan diferensiasi produk berdasarkan lingkungan, lokasi dan fisik sehingga berpengaruh pada penentuan harga. Dengan kondisi di atas, maka pengembang biasanya akan berusaha memahami karakteristik konsumen agar produk rumah hunian yang ditawarkan akan cepat diminati. Berdasarkan penjelasan diatas, maka penelitian ini bertujuan: Mendeskripsikan hubungan pada latar belakang konsumen menurut karaterisktiknya, yaitu sisi demografis (usia, kelompok keluarga), sisi geografidan sisi psikologi; Mendeskripsikan skala prioritas persepsi konsumen terhadap atribut rumah tinggal yang dikembangkan di Surabaya; Melakukan pemetaan persepsi konsumen terhadap atribut rumah tinggal yang dikembangkan di Surabaya.

\section{LANDASAN TEORI}

Perception isthe process by which an individual selects, organizes, and interprets stimuli into a meaningful and coherent picture of the world (Schiffman \& Kanuk, 2010). Jika dua orang mendapatkan stimuli dengan kondisi yang sama, maka cara setiap orang mengenal, menyeleksi, mengorganisir dan mengintepretasikan stimuli tersebut sangat bergantung pada kebutuhan, nilai dan ekspektasi masing-masing orang tersebut.

Menurut Schiffman \& Kanuk (2010), persepsi pada hakekatnya merupakan proses psikologis yang kompleks serta melibatkan aspek fisiologis. Proses psikologis dimulai dari adanya aktivitas memilih, mengorganisasikan dan menginterpretasikan sehingga konsumen mampu memberikan makna atas suatu obyek. Proses persepsi diawali dengan adanya stimuli yang mengenai panca indra dan disebut sebagai sensasi. Asal stimuli sangat beragam, ada yang berasal dari luar individu atau dari dalam diri individu. Faktor stimuli yang berasal dari luar dapat mempengaruhi pilihan konsumen, seperti kekontrasan atau perbedaan yang mencolok, kebaruan, intensitas, besarnya ukuran obyek, gerakan dan pengulangan. Faktor stimuli tersebut akan menarik perhatian konsumen sehingga secara perlahan masuk dalam benak atau pikiran konsumen. Faktor stimuli yang berasal dari dalam adalah pengharapan dan motivasi. Akibatnya akan timbul empat faktor penting dalam persepsi konsumen, yaitu: 
a. Selective Exposure

Konsumen cenderung akan memilih tayangan atau apa saja yang dilihat dan dirasakannya secara selektif. Berbagai informasi yang diingatnya akan mempengaruhi pilihannya.

b. Selective Attention

Konsumen cenderung selektif dengan memberikan perhatian yang tinggi pada kebutuhan yang sesuai dengan konsumen dan memberikan perhatian yang rendah pada kebutuhan yang tidak atau belum diperlukan.

c. Perceptual Defense

Konsumen secara tidak sadar akan melindungi diri dari stimuli yang dianggap membahayakan dirinya, serta melindungi diri dari hal-hal yang tidak sesuai dengan kebutuhan, keyakinan dan nilainilainya.

d. Perceptual Blocking

Konsumen akan menahan berbagai stimuli sesuai dengan kesadarannya.

Setelah mengalami stimuli, konsumen mengorganisasikan stimuli tersebut dengan mengelompokkan, menghubungkan stimuli yang dilihat supaya dapat diinterpretasikan sehingga mempunyai makna. Menurut Schiffman \& Kanuk (2010), terdapat tiga landasan utama pada organisasi persepsi, yaitu: figure dan ground, grouping, sertaclosure.

a. Gambar dan latar belakang (figure and ground)

Konsumen akan menghubungkan dan mengaitkan antara gambar dengan latar belakangnya yang terbatas, samar-samar dan secara berkesinambungan hingga memiliki makna.

b. Pengelompokan (grouping)

Konsumen cenderung mengelompokkan obyek stimuli yang memiliki kemiripan menjadi satu kelompok berdasarkan prinsip kedekatan, kesamaan dan berkesinambungan.

c. Penutup (closure)

Pada tahap ini, konsumen secara sadar atau tidak sadar akan mengingat semua informasi yang dimiliki agar mampu memberikan makna yang tepat. Stimuli yang tidak jelas seringkali menyulitkan untuk diintepretasikan, bahkan dapat menyebabkan kesalahan saat memberikan makna.Usaha apapun yang dilakukan pemasar tidak akan berarti apabila konsumen tidak dapat mempersepsikan secara tepat stimuli dari pemasar.

Pada umumnya semua konsumen adalah sama, sebab mereka memiliki keperluan, keinginan dan kebutuhan dengan berlandaskan latar belakang, pendidikan dan pengalaman. Cara bagaimana individu menanggapi suatu situasi tertentu adalah didasarkan atas sifat atau ciri-ciri yang dimiliki termasuk keputusan pembelian produk atau jasa. Terdapat sembilan kategori pembagian karakteristik konsumen berdasarkan segmentasi pasar, yaitu: demografi, geodemografi, personality traits, gaya hidup (life style), nilai dan kepercayaan sosial budaya (Schiffman \& Kanuk, 2010).

a. Segmentasi demografi: usia, jenis kelamin/gender, status pernikahan, siklus hidup keluarga, pendapatan, pendidikan dan pekerjaan.

b. Segmentasi geodemografi: segmentasi yang disesuaikan dengan keberadaan konsumen dikelompokkan memiliki kesamaan keuangan, selera, gaya hidup dan pola konsumsi.

c. Segmentasi personal traits: risk averse, open minded, reserved information seekers

d. Segmentasi gaya hidup

e. Segmentasi sosial budaya: budaya, cross-cultural atau global marketing.

Salah satu langkah untuk mengukur persepsi konsumen adalah melalui pemetaan persepsi (perceptual mapping). Teknik tersebut membantu bagaimana seorang pemasar membedakan produk dan jasa yang dilihat konsumen dalam persaingan merek pada satu atau beberapa karakteristik yang relevan (Schiffman \& Kanuk, 2010). Teknik ini juga berguna untuk memilih sasaran dan memutuskan bagaimana menentukan sasaran yang terpilih (Cravens \& Nigel, 2006).

Pemetaan persepsi menunjukkan posisi barang dan jasa yang dipilih konsumen sesuai dengan yang dirasakan. Tiap-tiap pilihan menempati tempat khusus, pilihan yang memiliki kesamaan akan saling berdekatan, sedangkan yang memiliki banyak perbedaan akan saling berjauhan (Ratnawati, 2002). Ilustrasi dapat dilihat pada Gambar 1. Peta pesepsi dari enam merek produk ditinjau dari dua dimensi, yaitu wantdan need. Semakin dekat posisi antara dua merek menunjukkan kemiripan kedua obyek tersebut dan menunjukkan tingginya tingkat persaingan di antara keduanya. Sebaliknya semakin jauh posisi antara dua merek semakin rendah tingkat kemiripan keduanya, demikian pula dengan tingkat persaingannya.

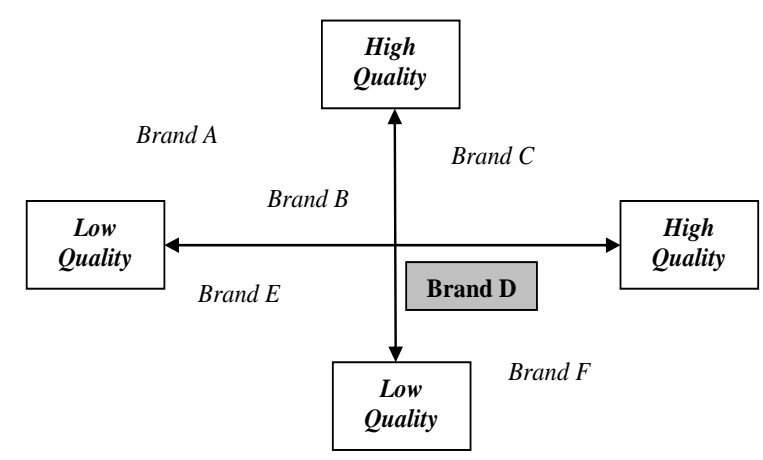

Gambar 1. Consumer Perception Map

Sumber: Cravens \& Nigel, 2006 
Menurut Amarta, perumahan adalah tempat hunian dari sekelompok keluarga yang hidup bersama dalam satu wilayah (2002). Definisi lain menyatakan perumahan adalah kelompok rumah yang berfungsi sebagai lingkungan tempat tinggal atau lingkungan hunian yang dilengkapi dengan prasarana dan sarana lingkungan (Musthofa, 2008). Saat ini pengembang dalam membangun perumahan selalu menyediakan prasarana dan sarana lingkungan untuk menarik minat pembeli, bahkan mereka saling bersaing dalam menawarkan fasilitas tersebut.

Oleh karena itu konsumen sebelum mengambil keputusan dalam pembelian rumah sebaiknya mempertimbangkan beberapa faktor yang disampaikan oleh Tjiptono \& Afandi (2006), yaitu:

1. Lingkungan

Lingkungan adalah segala sesuatu yang ada di sekitarnya, baik berupa benda hidup, benda mati, benda nyata ataupun abstrak, termasuk manusia lainnya, serta suasana yang terbentuk karena terjadinya interaksi di antara elemen-elemen di alam tersebut (Damanhuri, 2006). Lingkungan pemukiman merupakan kawasan perumahan dengan luas wilayah dan jumlah penduduk tertentu, yang dilengkapi dengan sistem prasarana, sarana lingkungan, tempat kerja terbatas dengan penataan ruang yang terencana serta teratur sehingga memungkinkan pelayanan dan pengelolaan yang optimal. Undang-undang menyatakan perumahan dan pemukiman merupakan satu kesatuan yang tidak terpisahkan. Perumahan, lingkungan pemukiman, serta prasarana dan sarana pendukungnya diperlukan dalam kawasan pemukiman untuk memenuhi fungsinya sebagai kebutuhan dasar manusia, pengembangan keluarga dan mendorong kegiatan ekonomi. Penghuni perumahan tidak hanya mengharapkan rumah yang baik, tetapi juga lingkungan yang aman, nyaman, menyenangkan, lengkap dengan berbagai fasilitasnya karena terkait dengan kesan eksklusif sehingga mempengaruhi pandangan konsumen dalam pemilihan produk properti (Wurtzebach \& Miles, 1994). Menurut UndangUndang No. 4 tahun 1992 Pasal 1 Ayat 6, sarana lingkungan adalah fasilitas penunjang yang lengkap meliputi fasilitas umum dan fasilitas sosial, yang berfungsi sebagai penyelenggaraan dan pengembangan kehidupan ekonomi, sosial dan budaya. Fasilitas berfungsi untuk memenuhi kebutuhan pembeli. Fasilitas umum (fasum) meliputi jalan, saluran air, listrik, pengelolaan sampah, lapangan olahraga, ruang terbuka hijau, sedangkan fasilitas sosial (fasos) meliputi sekolah, tempat ibadah, pasar, makam, poliklinik dan kantor pemerintahan (Penyempurnaan Kawasan Perumahan, 2004).

2. Lokasi

Lokasi adalah tempat rumah tinggal itu berada. Menurut Kauko (2006), beberapa faktor yang biasanya dipertimbangkan oleh konsumen dalam memilih lokasi rumah tinggal meliputi:

a. Aksesbilitas dan kedekatan: jarak ke tempat kerja dan jasa (-) dan sistem transportasi umum $(+)$.

b. Faktor sosial pada lingkungan: status sosial ekonomi (+) dan faktor eksternalitas yang disebabkan gangguan sosial (-) (contoh: perampokan).

c. Infrastruktur pelayanan di dalam lingkungan: ketersediaan layanan publik dan swasta (+).

d. Lingkungan yang keras/berwujud yaitu tinggi (-) atau rendahnya (+) tingkat kepadatan bangunan tinggi maupun lingkungan yang lembut/tidak berwujud yaitu gaya hidup, pencitraan positif (+), kebisingan, polusi (-).

e. Perkotaan: citrakota dankebijakan pemerintah Faktor lokasi sangatlah kompleks sebab terkait dengan skala makro perkotaan dan kebijakan tata ruang yang berhubungan pula dengan aspek ekonomi dan sosial budaya dalam pembentukan citra sebuah lokasi. Bila lokasi dipandang sebagai tapak maka terkait secara detil dengan keberadaan kualitas sebuah lahan di suatu wilayah, kondisi jalan, aksesbilitas ke lahan, kondisi lahan dan faktor lainnya.

3. Atribut Fisik Rumah

Menurut Guiltinan, Paul \& Madden (1997), atribut produk didefinisikan sebagai represent the specific features or physical characteristic that are designed into goods or service. Menurut Tjiptono $\&$ Afandi (2006), atribut fisik merupakan unsur yang dipandang penting oleh konsumen untuk dasar pengambilan keputusan pembelian, sebagai contoh: bahan bangunan, desain interior, luas tanah, luas bangunan, kemegahan rumah dan lain sebagainya.

Atribut fisik meliputi:

a. Kualitas Fisik

Kualitas rumah tinggal secara umum adalah mutu bahan yang digunakan saat membangun rumah hunian, misalnya batu bata, lantai keramik, kusen kayu meranti pada pintu dan jendela. Kualitas fisik khusus membutuhkan biaya yang relatif mahal karena mutu bahan yang khusus, seperti kusen kayu jati pada pintu dan jendela.

b. Desain Fisik

Pengaruh ekspresi eksterior bangunan adalah bentuk bangunan yang beraneka ragam di 
lingkungan sekitarnya. Jadi komposisi dan bentuk eksterior terhadap lingkungannya akan menimbulkan lingkungan baik atau buruk bahkan merusak lingkungan sekitarnya tergantung pada ukuran-ukuran, proporsi, keserasian bentuk yang dibuat dan faktor-faktor lainnya.

Tiga faktor penting yang harus dipenuhi di dalam bangunan adalah kekuatan, kegunaan dan keindahan. Untuk mewujudkan bentuk bangunan yang baik, ada empat faktor yang harus dipenuhi, yaitu estetika, struktur, kulit dan perlengkapan bangunan. Bentuk dan desain bangunan akan mempengaruhi harga jual rumah. Semakin sulit dan membutuhkan keterampilan yang tinggi serta desain bangunan yang mengikuti trend seperti model mediterania, model minimalis, atau model tropical akan menciptakan harga jual yang tinggi. Akan tetapi, properti dikatakan menarik apabila bentuk dan tampak luarnya sesuai dengan permintaan pasar.

4. Harga

Hargaadalah jumlah uang yang ditukarkan untuk memperoleh suatu produk (Ferrinadewa \& Darmawan, 2004). Masing-masing konsumen memiliki sensitivitas yang berbeda pada harga yang ditawarkan.Kualitas barang atau jasa turut menentukan tinggi atau rendahnya harga yang ditawarkan (Cummins, 1991). Dalam metode pemasaran, penetapan harga suatu produk atau jasa didasarkan atas posisi yang diinginkan dalam pasar, mencerminkan citra dan manfaatnya, nilai yang dirasakan, bagian pasar, volume penjualan dan keuntungan yang diinginkan serta tanggapan pembelian maupun pesaing terhadap harga tersebut. Terkait dengan penentuan harga rumah yang ditawarkan, maka akan menjadi pertimbangan tersendiri bagi konsumen dalam membandingkan antara harga rumah yang satu dengan harga rumah lainnya. Pembelian yang terjadi merupakan keputusan terbaik yang dibuat oleh konsumen di antara berbagai harga yang ditawarkan oleh pengembang. Konsumen dapat memilih cara pembayaran dengan beberapa metode sebagai berikut:

a. Tunai adalah konsumen membayar harga rumah sesuai harga jual rumah seluruhnya, sehingga di kemudian hari konsumen tidak lagi memiliki tanggungan terhadap biaya kepemilikan rumah yang dibeli dari pihak pengembang.

b. Kredit Pemilikan Rumah (KPR). Setiap pengembang menawarkan jenis KPR yang berbeda-beda sebagai cara pembayarannya, antara lain: KPR-BTN, KPR-Bank Swasta, KPR-Pengembang (In-House).

Sirgy, Grzeskowiak \& Su (2005) menemukan pada penelitian Varvoglis \& Sirgy (1984) serta Sirgy \& Johar (1985 a,b) bahwa pandangan tradisional tentang persepsi konsumen menurut teori fungsional harmoni adalah evaluasi psikologis konsumen terhadap rumah tinggal didasarkan pada perbandingan aspek utilitarian rumah denganfitur yang ideal.

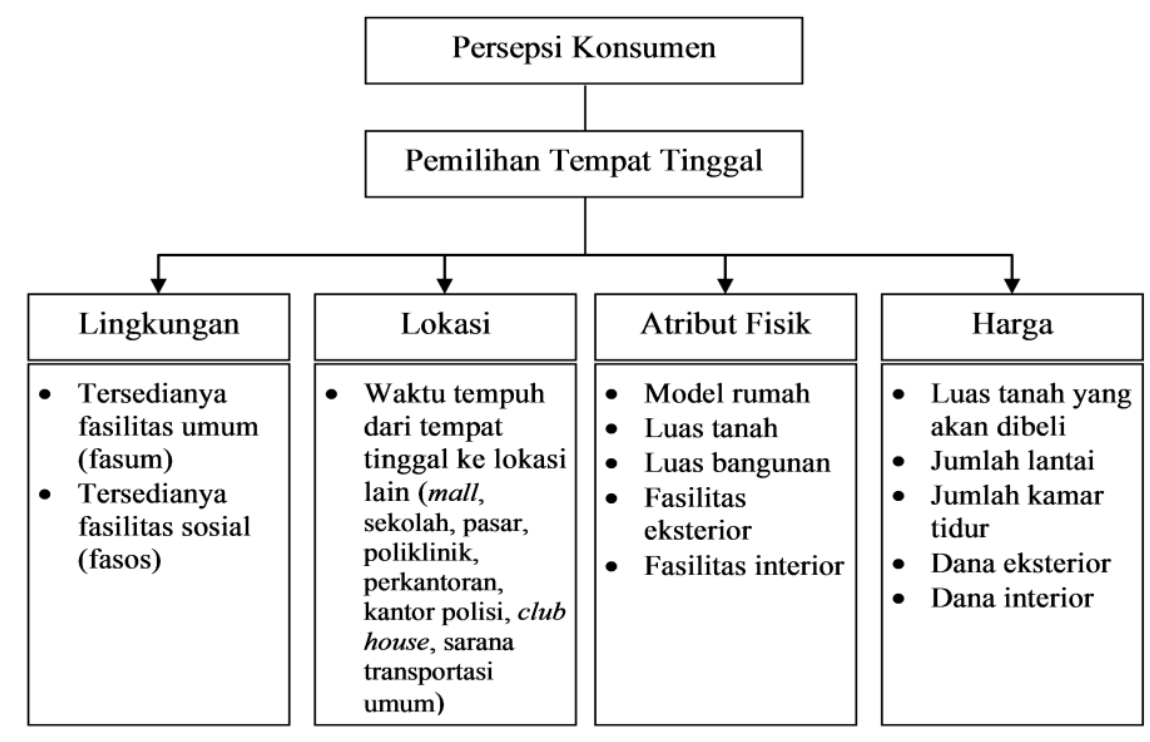

Gambar 2. Persepsi Konsumen Terhadap Atribut Rumah Tinggal

Sumber: Tjiptono \& Affandi, 2006: p.76. 
Demikian pula yang ditemukan pada penelitian Howell dan Frese (1983), Luger (1996) dan Vale (1998) yang memberikan contoh, pembeli rumah akan mempertimbangkan kualitas rumah,kisaran harga, kedekatan tempat tinggal ke area komersial, adanya fasilitas sosial, maupun pengaturan pembiayaan untuk pembelianrumah. Persepsi tersebut dipengaruhi secara positifoleh fungsional harmoni, artinya, semakin besar perbandingan antara fitur utilitarian yang dirasakan (contoh: kualitas rumah, denah rumah, biaya pembelian rumah dan biaya pemeliharaan) dengan fitur yang diinginkan oleh pembeli rumah, maka semakin besar pembeli termotivasi untuk membeli rumah tersebut.

Berdasarkan uraian di atas, penelitian ini akan difokuskan untuk mengetahui persepsi konsumen terhadap atribut rumah tinggal yaitu atribut lingkungan, lokasi, fisik, dan harga serta pemetaan persepsi. Persepsi yang berbeda-beda terutama dilatarbelakangi oleh faktor demografi, geodemografi, personality traitsdan gaya hidup (life style).

\section{METODE PENELITIAN}

Jenis penelitian yang digunakan adalah penelitian deskriptif, yaitu penelitian yang dilakukan untuk mengetahui variabel mandiri, baik satu variabel maupun lebih (independen) tanpa membuat perbandingan atau menghubungkan antara variabel yang satu dengan yang lain (Sugiyono, 2006). Penelitian ini mendeskripsikan persepsi konsumen terhadap atributatribut rumah tinggal (lingkungan, lokasi, atribut fisik dan harga) sesuai dengan faktor demografi, geodemografi, personality traits, gaya hidup (life style).

Populasi adalah kumpulan menyeluruh suatu obyek yang merupakan perhatian peneliti. Obyek peneliti dapat berupa makhluk hidup, benda, sistem, prosedur dan lain-lain. Sampel adalah bagian dari populasi yang representatif untuk diteliti (Kountur, 2007). Populasi penelitian ini adalah seluruh penghuni rumah tinggal pada perumahan di Surabaya Barat dan Surabaya Timur. Teknik penarikan sampel menggunakan convenience sampling, yaitu setiap anggota dari populasi diambil sebagai sampel dengan kriteria adalah penghuni yang dapat ditemui pada saat penyebaran kuesioner. Besaran sampel menunjukkan banyaknya anggota yang mewakili populasi, yang selanjutnya akan dianalisis sesuai dengan standar deviasi yang diharapkan, kesalahan estimasi yang diharapkan dan jenis penelitian. Penentuan besaran sampel yang diteliti menggunakan rumus:

$n=\frac{Z^{2} \cdot p(1-p)}{E^{2}}$

$$
\begin{aligned}
& =\frac{1,96^{2} \cdot 0,5((1-0,5))}{0,05^{2}} \\
& =384,16 \\
& =384 \text { Rumah }
\end{aligned}
$$

Keterangan:

$\mathrm{Z}$ = Nilai yang diperoleh dari tabel $\mathrm{Z}$ pada tingkat keyakinan tertentu (level of confidence untuk penelitian sosial biasanya $95 \%$ atau $99 \%$ )

$\mathrm{p}=$ Proporsi

$\mathrm{E}=$ Error of estimate. Kesalahan yang dapat ditoleransi dalam level of confidence tertentu $(\overline{\mathrm{X}}-\mu)$

Definisi operasional penelitian adalah:

a. Persepsi konsumen ialah penilaian dan pilihan konsumen tentang atribut-atribut rumah tinggal yang diminati dan dipilih sesuai dengan karakteristik konsumen menurut faktor demografi (usia, jenis kelamin, status pernikahan, penghasilan per bulan, pendidikan, pekerjaan), geodemografi (jumlah rumah yang dimiliki, waktu-periode pembelian rumah, pengguna-status rumah) dan personal traits (motivasi-niat pembelian rumah).

b. Atribut rumah tinggal ialah atribut yang terkait dengan rumah tinggal yang diminati, meliputi atribut lingkungan (tersedianya fasilitas umum dan fasilitas sosial), atribut lokasi (waktu tempuh), atribut fisik (model rumah yang disukai, luas tanah yang dimiliki, luas bangunan yang dimiliki, fasilitas eksterior dan interior yang diminati) dan atribut harga (luas tanah yang akan dibeli, jumlah lantai, jumlah kamar tidur dana eksterior dan dana interior).

Data diolah dengan menggunakan SPSS 17.00 melalui teknik analisis data tabulasi silang dan analisis Chi Square untuk mendeskripsikan secara ringkas segmentasi konsumen dengan atribut-atribut rumah tinggal serta melihat keeratan hubungan kedua faktor tersebut. Dasar pengambilan keputusan berdasarkan nilai probabilitas dan menggunakan tingkat signifikansi pada $(\alpha)=0,05$, yaitu:

$\mathbf{H}_{0}: \mathrm{P}>\alpha$ : Tidak ada hubungan yang signifikan antara dua variabel

$\mathbf{H}_{1}: \mathrm{P}<\alpha$ : Ada hubungan yang signifikan antara dua variabel

Persepsi konsumen terhadap atribut rumah tinggal dipetakan dengan menggunakan Microsoft Excel. Masing-masing variabel atribut rumah tinggal pada masing-masing perumahan di Surabaya Barat dan Surabaya Timur dicari nilai rata-ratanya kemudian ditentukan besaran bobotnya berdasarkan nilai rata-rata yang telah dihitung sebelumnya. 
Pembobotan yang ditemukan dikalikan kembali dengan nilai rata-rata masing-masing variabel pada masing-masing perumahan untuk menentukan nilai rata-rata tertimbang secara keseluruhan. Hasilnya akan menentukan peta persepsi konsumen tersebut.

\section{HASIL PENELITIAN DAN PEMBAHASAN}

Berdasarkan perhitungan jumlah sampel yang telah disebutkan pada rumus (1), maka kuesioner disebarkan kepada 400 responden selama dua minggu.Akan tetapi, hanya 384 kuesioner yang lengkap jawabannya untuk dimasukkan dalam pengolahan data. Kuesioner dibagikan kepada para penghuni yang bertempat tinggal di perumahan Surabaya Timur dan Surabaya Barat. Dari 384 kuesioner, ada sebanyak 17 responden yang tidak berminat dengan rencana pembelian rumah berikutnya, sehingga mereka tidak menjawab pertanyaan selanjutnya. Tabel 1 menunjukkan sebaran informasi terkait segmentasi demografi (jenis kelamin, usia, status pernikahan, pendidikan). Tabel tersebut menunjukkan bahwa mayoritas responden adalah pria dengan bidang pekerjaan wiraswasta, berusia 33-45 tahun dan mayoritas berstatus sudah menikah dengan pendidikan dibawah S1 (setara diploma).

Tabel 2 menunjukkan bahwa 64\% responden adalah pria dengan penghasilan lebih dari Rp 10 jutaRp 20 juta yang berusia 33-45 tahun. Mayoritas responden sudah menikah dengan latar belakang pendidikan yang berbeda-beda dan dimasukkan kategori lain-lain, yaitu setara tingkat diploma.

Tabel 3 menunjukkan bahwa responden pria yang berusia 33-45 tahun dan 83\% di antaranya sudah memiliki rumah sendiri dengan status milik sendiri. Penelitian menunjukkan adanya hubungan yang kuat secara signifikan antara usia dan status pernikahan konsumen dengan status kepemilikan rumah karena nilai probabilitas lebih kecil daripada tingkat signifikansi $(0,002$ dan $0,029<0,05)$.

Tabel 1. Latar Belakang Responden Ditinjau dari Pekerjaan

\begin{tabular}{|c|c|c|c|c|c|}
\hline \multirow{2}{*}{\multicolumn{2}{|c|}{ Keterangan }} & \multicolumn{3}{|c|}{ Pekerjaan } & \multirow{3}{*}{\begin{tabular}{|l|} 
Total \\
344 \\
\end{tabular}} \\
\hline & & Wiraswasta & Pegawai Swasta & Lainnya & \\
\hline \multirow{2}{*}{ Jenis kelamin } & Pria & 277 & 55 & 12 & \\
\hline & Wanita & 34 & 4 & 2 & 40 \\
\hline \multirow{4}{*}{ Usia } & $17-25$ tahun & 9 & 0 & 0 & 9 \\
\hline & 26 - 32 tahun & 34 & 3 & 2 & 39 \\
\hline & 33 - 45 tahun & 232 & 49 & 8 & 289 \\
\hline & $>45$ tahun & 36 & 7 & 4 & 47 \\
\hline \multirow{3}{*}{ Status } & Belum menikah & 5 & 2 & 0 & 7 \\
\hline & Menikah & 302 & 55 & 13 & 370 \\
\hline & Duda/ Janda & 4 & 2 & 1 & 7 \\
\hline \multirow{4}{*}{ PendidikanTerakhir } & $<\mathrm{SMU}$ & 11 & 0 & 2 & 13 \\
\hline & SMU & 47 & 7 & 0 & 54 \\
\hline & $\mathrm{S} 1$ & 27 & 15 & 2 & 44 \\
\hline & Lain-lain & 226 & 37 & 10 & 273 \\
\hline
\end{tabular}

Tabel 2. Latar Belakang Responden Ditinjau dari Penghasilan Per Bulan

\begin{tabular}{|c|c|c|c|c|c|}
\hline \multicolumn{2}{|c|}{ Keterangan } & \multicolumn{3}{|c|}{ Penghasilan per bulan } & \multirow[t]{2}{*}{ Total } \\
\hline & & $<1,2$ juta -10 juta & $>10$ juta -20 juta & $>20$ juta & \\
\hline \multirow{2}{*}{ Jenis kelamin } & Pria & 129 & 205 & 10 & 344 \\
\hline & Wanita & 16 & 21 & 3 & 40 \\
\hline \multirow{4}{*}{ Usia } & $17-25$ tahun & 3 & 6 & 0 & 9 \\
\hline & 26 - 32 tahun & 23 & 15 & 1 & 39 \\
\hline & 33 - 45 tahun & 97 & 185 & 7 & 289 \\
\hline & $>45$ tahun & 22 & 20 & 5 & 47 \\
\hline \multirow{3}{*}{ Status } & Belum menikah & 3 & 4 & 0 & 7 \\
\hline & Menikah & 137 & 221 & 12 & 370 \\
\hline & Duda/Janda & 5 & 1 & 1 & 7 \\
\hline \multirow{4}{*}{ PendidikanTerakhir } & $<\mathrm{SMU}$ & 3 & 8 & 2 & 13 \\
\hline & SMU & 15 & 35 & 4 & 54 \\
\hline & $\mathrm{S} 1$ & 22 & 21 & 1 & 44 \\
\hline & Lain-lain & 105 & 162 & 6 & 273 \\
\hline
\end{tabular}


Tabel 3. Hubungan Demografi Responden dengan Status Kepemilikan Rumah

\begin{tabular}{|c|c|c|c|c|c|c|}
\hline \multirow{2}{*}{\multicolumn{2}{|c|}{ Keterangan }} & \multicolumn{3}{|c|}{ Status Rumah } & \multirow{3}{*}{$\begin{array}{l}\text { Total } \\
344\end{array}$} & \multirow{3}{*}{$\begin{array}{c}\text { Asymp. Sig. } \\
\text { (2-sided) } \\
.240\end{array}$} \\
\hline & & \multirow{2}{*}{$\begin{array}{c}\text { Sewa } \\
14\end{array}$} & \multirow{2}{*}{$\begin{array}{c}\text { Milik Sendiri } \\
271\end{array}$} & \multirow{2}{*}{$\begin{array}{c}\text { Milik Orang Tua } \\
59\end{array}$} & & \\
\hline Jenis kelamin & Pria & & & & & \\
\hline & Wanita & 4 & 30 & 6 & 40 & \\
\hline \multirow[t]{4}{*}{ Usia } & 17 - 25 tahun & 0 & 5 & 4 & 9 & \multirow{4}{*}{.002} \\
\hline & 26 - 32 tahun & 3 & 25 & 11 & 39 & \\
\hline & 33 - 45 tahun & 9 & 239 & 41 & 289 & \\
\hline & $>45$ tahun & 6 & 32 & 9 & 47 & \\
\hline \multirow[t]{3}{*}{ Status } & Belum menikah & 0 & 3 & 4 & 7 & \multirow{3}{*}{.029} \\
\hline & Menikah & 17 & 294 & 59 & 370 & \\
\hline & Duda/Janda & 1 & 4 & 2 & 7 & \\
\hline \multirow{4}{*}{$\begin{array}{l}\text { Pendidikan } \\
\text { Terakhir }\end{array}$} & $<\mathrm{SMU}$ & 2 & 9 & 2 & 13 & \multirow{4}{*}{.103} \\
\hline & SMU & 4 & 41 & 9 & 54 & \\
\hline & S1 & 1 & 30 & 13 & 44 & \\
\hline & Lain-lain & 11 & 221 & 41 & 273 & \\
\hline
\end{tabular}

Tabel 4.Hubungan Demografi Responden dengan Jumlah Rumah Tinggal

\begin{tabular}{|c|c|c|c|c|c|c|c|}
\hline & & \multicolumn{4}{|c|}{ Jumlah Rumah yang Dimiliki } & \multirow{2}{*}{ Total } & \multirow{2}{*}{$\begin{array}{c}\text { Asymp. Sig } \\
\text { (2-sided) }\end{array}$} \\
\hline & & Tidak ada & 1 & 2 & $\geq 3$ & & \\
\hline \multirow{2}{*}{ Jenis kelamin } & Pria & 18 & 283 & 41 & 2 & 344 & \multirow{2}{*}{.199} \\
\hline & Wanita & 0 & 36 & 3 & 1 & 40 & \\
\hline \multirow{4}{*}{ Usia } & $17-25$ tahun & 2 & 7 & 0 & 0 & 9 & \multirow{4}{*}{.000} \\
\hline & $26-32$ tahun & 10 & 24 & 5 & 0 & 39 & \\
\hline & 33 - 45 tahun & 4 & 248 & 34 & 3 & 289 & \\
\hline & $>45$ tahun & 2 & 40 & 5 & 0 & 47 & \\
\hline \multirow{3}{*}{ Status } & Belum menikah & 0 & 7 & 0 & 0 & 7 & \multirow{3}{*}{.804} \\
\hline & Menikah & 17 & 307 & 43 & 3 & 370 & \\
\hline & Duda/Janda & 1 & 5 & 1 & 0 & 7 & \\
\hline \multirow{4}{*}{ PendidikanTerakhir } & $<\mathrm{SMU}$ & 0 & 8 & 5 & 0 & 13 & \multirow{4}{*}{.019} \\
\hline & SMU & 3 & 42 & 9 & 0 & 54 & \\
\hline & $\mathrm{S} 1$ & 5 & 33 & 6 & 0 & 44 & \\
\hline & Lain-lain & 10 & 236 & 24 & 3 & 273 & \\
\hline
\end{tabular}

Tabel 5.Hubungan Demografi Responden dengan Niat Beli Rumah

\begin{tabular}{|c|c|c|c|c|c|}
\hline \multirow{2}{*}{\multicolumn{2}{|c|}{ Keterangan }} & \multicolumn{2}{|c|}{ Niat Beli Rumah } & \multirow{2}{*}{ Total } & \multirow{2}{*}{ Asymp. Sig.(2-sided) } \\
\hline & & $\mathrm{Ya}$ & Tidak & & \\
\hline \multirow{2}{*}{ Jenis kelamin } & Pria & 328 & 16 & 344 & \multirow{2}{*}{.531} \\
\hline & Wanita & 39 & 1 & 40 & \\
\hline \multirow{3}{*}{ Rencana Beli } & 2-3 tahun & 32 & 0 & 32 & \multirow{3}{*}{-} \\
\hline & 3-4 tahun & 127 & 0 & 127 & \\
\hline & $>4$ tahun & 208 & 0 & 208 & \\
\hline
\end{tabular}

Tabel 4 menunjukkan bahwa $86 \%$ responden pria telah memiliki rumah (1 unit) untuk tempat tinggal dan terdapat hubungan yang signifikan antara usia dan pendidikan dengan jumlah rumah yang dimiliki.

Tabel 5 menunjukkan bahwa 95\% responden pria berniat membeli rumah lagi. Sebanyak $60 \%$ responden merencanakan untuk membeli rumah empat tahun lagi. Akan tetapi, variabel niat beli dengan demografi dan rencana beli tidak menunjukkan adanya hubungan yang signifikan karena nilai probabilitas lebih besar daripada tingkat signifikansi $(0,531>0,05)$.

Tabel 6 menunjukkan bahwa 52\% responden pria lebih menyukai daerah Surabaya Barat daripada Surabaya Timur (41\%). Responden memiliki rumah dengan luas bangunan (LB) dan luas tanah (LT) antara 151-200 $\mathrm{m}^{2}$ dan berencana untuk membeli lagi rumah yang luasnya sama dengan kepemilikan saat ini. Rumah yang diinginkan 2 (dua) lantai, model rumah tropis di daerah Perumahan Citra Raya dengan fasilitas pendukung taman. 
Tabel 6. Latar Belakang Demografi dengan Atribut Rumah Tinggal

\begin{tabular}{|c|c|c|c|c|}
\hline \multirow{2}{*}{\multicolumn{2}{|c|}{ Keterangan }} & \multicolumn{2}{|c|}{ Jenis Kelamin } & \multirow{2}{*}{ Tota } \\
\hline & & Pria & Wanita & \\
\hline \multirow[t]{3}{*}{ Daerah yang Disukai } & Sby Utara & 2 & 0 & 2 \\
\hline & Sby Timur & 134 & 15 & 149 \\
\hline & Sby Barat & 192 & 24 & 216 \\
\hline \multirow[t]{3}{*}{ Ukuran Lahanyang dimiliki } & $<150 \mathrm{~m}^{2}$ & 40 & 10 & 50 \\
\hline & $151-200 \mathrm{~m}^{2}$ & 219 & 19 & 238 \\
\hline & $201-400 \mathrm{~m}^{2}$ & 69 & 10 & 79 \\
\hline \multirow[t]{3}{*}{ Ukuran Bangunanyang dimiliki } & $<150 \mathrm{~m}^{2}$ & 30 & 4 & 34 \\
\hline & $151-200 \mathrm{~m}^{2}$ & 226 & 26 & 252 \\
\hline & $201-400 \mathrm{~m}^{2}$ & 72 & 9 & 81 \\
\hline \multirow[t]{3}{*}{ Ukuran Lahan yang diminati } & $<150 \mathrm{~m}^{2}$ & 4 & 0 & 4 \\
\hline & $151-200 \mathrm{~m}^{2}$ & 249 & 27 & 276 \\
\hline & $201-400 \mathrm{~m}^{2}$ & 75 & 12 & 87 \\
\hline \multirow[t]{3}{*}{ Ukuran Bangunan diminati } & $<150 \mathrm{~m}^{2}$ & 153 & 21 & 174 \\
\hline & $151-200 \mathrm{~m}^{2}$ & 165 & 17 & 182 \\
\hline & $201-400 \mathrm{~m}^{2}$ & 10 & 1 & 11 \\
\hline \multirow[t]{3}{*}{ Jml lantai rumah yang diinginkan } & 1 tingkat & 2 & 0 & 2 \\
\hline & 2 tingkat & 251 & 25 & 276 \\
\hline & 3 tingkat & 75 & 14 & 89 \\
\hline \multirow[t]{4}{*}{ Model Rumah } & Mediteran & 42 & 10 & 52 \\
\hline & Tropis & 161 & 20 & 181 \\
\hline & Minimalis & 60 & 5 & 65 \\
\hline & Eropa & 65 & 4 & 69 \\
\hline \multirow[t]{6}{*}{ Perumahan yang Disukai } & Citraland & 137 & 19 & 156 \\
\hline & Pakuwon Indah & 57 & 6 & 63 \\
\hline & Pakuwon City & 109 & 12 & 121 \\
\hline & Galaxy Bumi Permai & 21 & 2 & 23 \\
\hline & Kertajaya Indah & 2 & 0 & 2 \\
\hline & Sutorejo & 2 & 0 & 2 \\
\hline \multirow[t]{4}{*}{ Fasilitas Pendukung } & Kolam Renang & 49 & 5 & 54 \\
\hline & Taman & 244 & 25 & 269 \\
\hline & Carport & 21 & 6 & 27 \\
\hline & Kanopi & 14 & 3 & 17 \\
\hline
\end{tabular}

Tabel 7. Hubungan Penghasilan dengan Dana Renovasi

\begin{tabular}{|c|c|c|c|c|c|c|}
\hline \multirow{2}{*}{\multicolumn{2}{|c|}{ Keterangan }} & \multicolumn{3}{|c|}{ Penghasilan per Bulan } & \multirow{2}{*}{ Total } & \multirow{2}{*}{$\begin{array}{l}\text { Asymp. Sig. } \\
\text { (2-sided) }\end{array}$} \\
\hline & & $\geq 1,2-10$ juta & $\geq 10-20$ juta & $20 \geq$ juta & & \\
\hline \multirow[t]{3}{*}{ Jml kamar tidur } & 3 kamar & 5 & 1 & 0 & 6 & \multirow{3}{*}{.182} \\
\hline & 4 kamar & 38 & 53 & 4 & 95 & \\
\hline & $>4$ kamar & 101 & 159 & 6 & 266 & \\
\hline \multirow[t]{4}{*}{ Dana eksterior } & $<4$ juta & 6 & 4 & 0 & 10 & \multirow{4}{*}{.001} \\
\hline & 4-7 juta & 101 & 148 & 1 & 250 & \\
\hline & $>7-10$ juta & 19 & 31 & 6 & 56 & \\
\hline & $>10$ juta & 18 & 30 & 3 & 51 & \\
\hline \multirow[t]{4}{*}{ Dana interior } & $<4$ juta & 4 & 10 & 0 & 14 & \multirow{4}{*}{.000} \\
\hline & 4-7 juta & 98 & 126 & 1 & 225 & \\
\hline & $>7-10$ juta & 13 & 36 & 7 & 56 & \\
\hline & $>10$ juta & 29 & 41 & 2 & 72 & \\
\hline
\end{tabular}

Tabel 7 menunjukkan bahwa mayoritas responden menginginkan jumlah kamar lebih dari empat, meskipun hubungan kedua variabel tidak signifikan, sedangkan kebutuhan dana untuk renovasi interior dan eksterior berhubungan secara signifikan dengan penghasilan per bulan. Hal ini dapat dilihat pada nilai probabilitas 0,001 dan 0,000 yang lebih kecil daripada tingkat signifikansi 0,05 . Responden bersedia 
mengeluarkan dana sebesar Rp 4 juta-Rp 7 juta untuk renovasi eksterior $(68 \%)$ dan renovasi interior $(61 \%)$.

Sebelum memutuskan pembelian rumah, responden melakukan penyusunan prioritas variabel fasilitas dari yang paling penting, yaitu dengan melihat nilai mean terbesaryang meliputi air, listrik, telepon, pengelolaan sampah, lapangan olah raga dan ruang terbuka hijau seperti pada Tabel 8 . Hal ini menunjukkan bahwa responden lebih mempertimbangkan tersedianya utilitas utama dalam perumahan dibandingkan fasilitas lainnya, seperti ruang terbuka hijau untuk daerah resapan untuk mengurangi banjir di wilayah tertentu. Hal tersebut kemungkinan disebabkan adanya beberapa perumahan di Surabaya yang memang belum memiliki fasilitas utama, yaitu air, listrik dan telepon terutama perumahan-perumahan di Surabaya Barat.

Tabel 9 menunjukkan persepsi konsumen tentang fasilitas sosial yang seharusnya disediakan oleh pengembang dalam perumahan untuk penghuni yang ditunjukkan dengan nilai mean terbesar sampai nilai mean terkecil, yaitu pengembang perlu menyediakan pasar, sarana transportasi, tempat ibadah, perkantoran, sekolah, sarana rekreasi, rumah sakit, makam dan club house. Apabila fasilitas tersebut tidak dapat disediakan di dalam perumahan, setidaknya berjarak tidak terlalu jauh dari lokasi perumahan. Dengan kata lain, letak fasilitas tersebut relatif cukup dekat dengan lokasi perumahan dan ada kemungkinan disediakan oleh pengembang perumahan lain di sekitar perumahan yang diminati konsumen. Fasilitas sosial ini juga menjadi salah satu program pemasaran bagi pengembang untuk menarik minat konsumen melakukan pembelian pada perumahan-perumahan yang diminati.

\section{Tabel 8. Fasilitas Umum}

\begin{tabular}{lc}
\hline \multicolumn{1}{c}{ Fasilitas Umum } & Mean \\
\hline Air & 4.30 \\
Listrik & 4.10 \\
Telepon & 3.93 \\
Pengelolaan sampah & 3.34 \\
Lapangan olah raga & 3.17 \\
Ruang terbuka hijau & 2.15 \\
\hline
\end{tabular}

Tabel 9. Fasilitas Sosial

\begin{tabular}{lc}
\hline \multicolumn{1}{c}{ Fasilitas Sosial } & Mean \\
\hline Pasar & 6.82 \\
Sarana transportasi & 6.53 \\
Tempat ibadah & 6.34 \\
Perkantoran & 5.42 \\
Sekolah & 5.19 \\
Sarana rekreasi & 4.37 \\
Rumah sakit & 3.65 \\
Makam & 3.52 \\
Club house & 3.15 \\
\hline
\end{tabular}

\section{Tabel 10. Waktu Tempuh}

\begin{tabular}{lc}
\hline Waktu Tempuh Menuju & Mean \\
\hline Menuju perkantoran & 6.52 \\
Menuju pusat perbelanjaan & 5.94 \\
Menuju sarana transportasi & 5.94 \\
Menuju kantor polisi & 5.89 \\
Menuju poliklinik & 3.63 \\
Menuju club house & 3.52 \\
Menuju pasar tradisional & 2.32 \\
Menuju sekolah & 2.25 \\
\hline
\end{tabular}

Pemetaan Fasilitas Umum

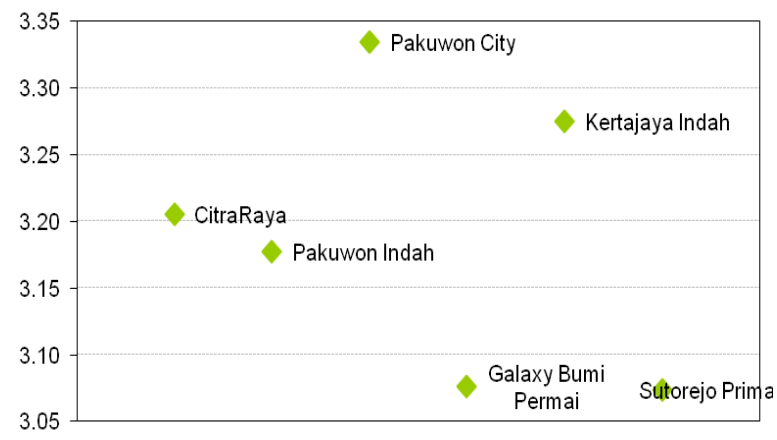

\section{Gambar 3. Persepsi Konsumen Berdasarkan Atribut} Fasilitas Umum

Tabel 10 menunjukkan skala prioritas konsumen dalam memilih rumah tinggal berdasarkan waktu tempuh dari rumah tinggal menuju lokasi lainnya dimulai dari waktu tempuh yang paling pendek sampai waktu tempuh yang paling lama, yaitu waktu yang dibutuhkan konsumen dari rumah tinggal menuju sekolah, kemudian ke pasar tradisional, club house, poliklinik, kantor polisi, sarana transportasi terdekat, pusat perbelanjaan, serta yang terakhir waktu tempuh menuju perkantoran. Hal tersebut dapat diartikan bahwa kegiatan rutin penghuni sangat terkait dengan kebutuhan pendidikan dan pangan untuk anak-anak serta penghuni lainnya termasuk juga kebutuhan kesehatan dan keamanan di saat genting. Waktu yang dibutuhkan ke tempat kerja bukan menjadi pertimbangan utama.

Gambar 3 menunjukkan pemetaan persepsi konsumen terhadap atribut rumah tinggal yang disediakan pengembang di wilayah Surabaya Timur dan Surabaya Barat. Pemetaan yang dilakukan meliputi atribut fasilitas umum, fasilitas sosial, desain arsitektur dan waktu tempuh.

Gambar 3 menunjukkan bahwa konsumen mempersepsikan perumahan di Surabaya Timur, yaitu Pakuwon City menduduki posisi paling tinggi dibandingkan perumahan lainnya dalam hal penyediaan fasilitas umum seperti air, telepon, listrik, pengelolaan sampah, lapangan olah raga dan ruang 
terbuka hijau. Posisi terendah untuk indikator fasilitas umum adalah Galaxi Bumi Permai dan Sutorejo Prima. Perumahan Citra Raya memiliki posisi lebih tinggi dibanding Pakuwon Indah untuk kelompok daerah perumahan yang diminati di Surabaya Barat.

Gambar 4 menunjukkan bahwa konsumen mempersepsikan Perumahan Kertajaya Indah mengungguli Pakuwon City dalam penyediaan fasilitas sosial seperti sekolah, tempat ibadah, pasar, makam, rumah sakit, club house, perkantoran, sarana transportasi dan sarana rekreasi. Akan tetapi, fasilitas tersebut belum semuanya tersedia dengan lengkap karena ada beberapa fasilitas yang masih sedang dibangun. Galaxy Bumi Permai dan Sutorejo Prima menepati posisi paling rendah dalam persepsi konsumenkarena kedua perumahan tersebut terkendala dengan luas pengembangan perumahan sehingga sangat minim fasilitas sosial. Untuk wilayah Surabaya Barat, Citra Raya memiliki posisi lebih tinggi dibanding Pakuwon Indah.

Pada Gambar 5 ditunjukkan bahwa konsumen mempersepsikan Perumahan Pakuwon City menduduki posisi paling tinggi dibandingkan perumahan lainnya untuk faktor desain arsitektur, baik secara desain eksterior maupun desain interior.

Pemetaan Fasilitas Sosial

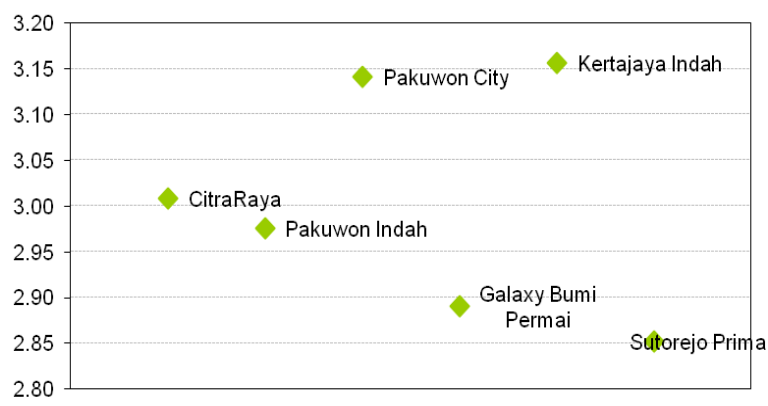

Gambar 4. Persepsi Konsumen Berdasarkan Atribut Fasilitas Sosial

Pemetaan Desain Arsitektur

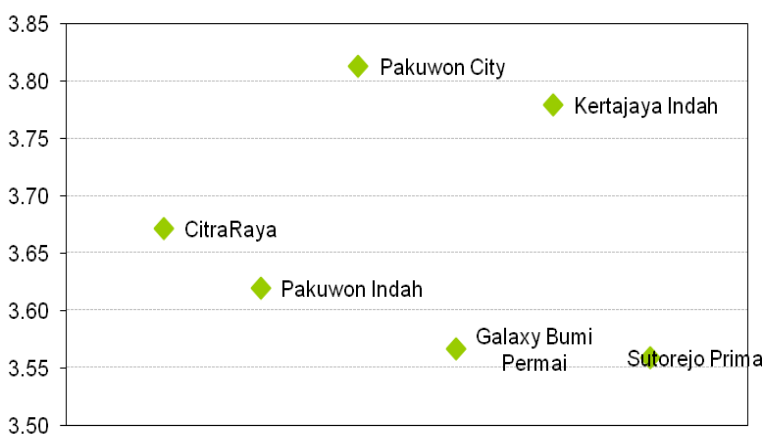

Gambar 5. Persepsi Konsumen Berdasarkan Desain Arsitektur

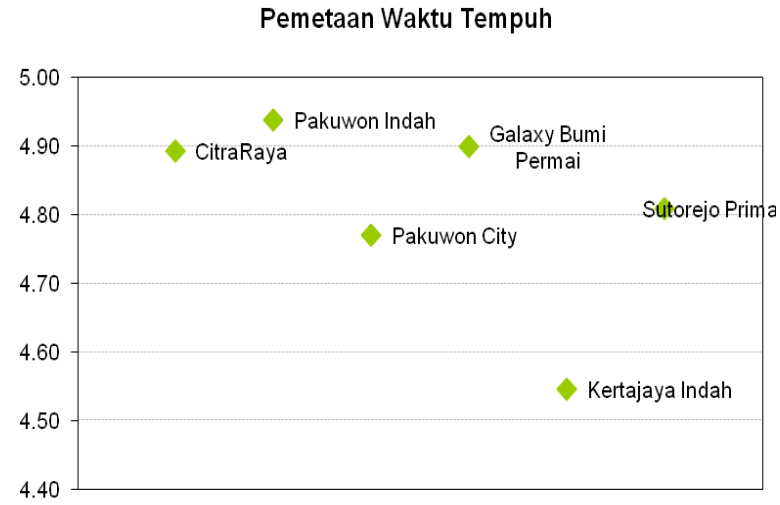

\section{Gambar 6. Persepsi Konsumen Berdasarkan Waktu Tempuh}

Pada Gambar 6 ditunjukkan bahwa Perumahan Kertajaya Indah di Surabaya Timur menempati posisi terendah dibanding Perumahan Pakuwon City, Galaxy Bumi Permai dan Sutorejo Prima dalam hal waktu tempuh dari rumah tinggal menuju lokasi lainnya. Untuk wilayah Surabaya Barat, Citra Raya menempati posisi di bawah Pakuwon Indah. Hal ini berarti letak Perumahan Kertajaya Indah dan Citra Raya memiliki waktu tempuh tercepat menuju lokasi lain (pasar, sekolah, poliklinik, pusat perbelanjaan dan lain-lain). Perumahan Kertajaya Indah memiliki lokasi yang strategis karena merupakan perumahan pertama di wilayah Surabaya Timur yang dibangun dengan jalan yang lebar, dilalui transportasi umum, serta dekat dengan beberapa sekolah, pasar dan kantor pemerintahan. Perumahan Citra Raya memiliki keunggulan karena menyediakan fasilitas umum dan fasilitas sosial yang cukup lengkap di dalam lingkungan perumahan itu sendiri. Hal ini terkait dengan rencana awal pembangunan perumahan tersebut untuk menjadi kota mandiri.

\section{KESIMPULAN DAN SARAN}

Dari pembahasan yang telah dilakukan, dapat diambil beberapa kesimpulan sebagai berikut: Mayoritas responden adalah pria yang sudah menikah dengan bidang pekerjaan wiraswasta, berusia 33 tahun-45 tahun, dengan tingkat pendidikan di bawah S1 (setara diploma). Responden berpenghasilan lebih dari Rp10 juta-Rp 20 juta dan sudah memiliki rumah sendiri. $96 \%$ responden berniat membeli rumah lagi pada periode 4 tahun lagi. Rumah yang diinginkan bertipe dua jumlah dengan model rumah tropis seperti di perumahan Citra Raya serta memiliki fasilitas pendukung taman sehingga menimbulkan suasana asri pada lingkungan perumahan tersebut.

Fasilitas umum seperti air, listrik dan telepon dan fasilitas sosial seperti sekolah, pasar dan sarana 
transportasi merupakan prioritas utama. Pertimbangan lain konsumen adalah waktu tempuh tercepat yang dibutuhkan konsumen dari rumah tinggal menuju lokasi lain seperti ke sekolah dan pasar tradisional.

Peta persepsi konsumen terhadap perumahan di wilayah Surabaya Timur menunjukkan bahwa Perumahan Pakuwon City memiliki keunggulan pada atribut lingkungan yaitu fasilitas umum dan atribut fisik yaitu desain arsitektur dibanding Perumahan Kertajaya Indah, Galaxi Bumi Permai dan Sutorejo Indah. Di wilayah Surabaya Barat, Perumahan Citra Raya memiliki keunggulan pada atribut lingkungan untuk fasilitas umum dan fasilitas sosial, serta atribut fisik khususnya desain arsitektur apabila dibandingkan dengan Perumahan Pakuwon Indah. Akan tetapi, Perumahan Kertajaya Indah di Surabaya Timur dan Citra Raya di Surabaya Barat menempati posisi waktu tempuh tercepat untuk menuju lokasi lain.

Sehubungan dengan adanya beberapa kesimpulan di atas, selanjutnya dapat diberikan beberapa saran sebagai berikut: Pengembang sebaiknya memiliki kerjasama dengan PLN, PDAM dan perusahaan telekomunikasi untuk menyediakan fasilitas umum karena fasilitas tersebut sangat dibutuhkan oleh konsumen yang akan membeli rumah. Pengembang sebaiknya menjalin kerjasama dengan pihak lain apabila tidak mampu menyediakan sendiri fasilitas sosial, seperti pasar dan sekolah. Pengembang sebaiknya bekerjasama dengan pihak lain atau penghuni untuk menciptakan ruang terbuka hijau (RTH) agar tercipta keseimbangan alam sehingga lingkungan menjadi asri dan nyaman.

\section{Ucapan Terima Kasih}

Saya sampaikan kepada Pralistya dan Meiranti yang telah membantu menyebarkan kuesioner untuk menyusun karya tulis ini.

\section{DAFTAR REFERENSI}

Amarta. 2002. Perumahan. Jakarta: PT. Gramedia. Cahyono. 2008.Bisnis Properti Tahun Depan Diprediksi Naik Pesat, (www.ciputra.com/ciputra cetak/0604/13/Properti/2573835.htm, diakses 5 Mei 2008)

Cravens, D.W. \& Nigel, F.P. 2006. Strategic Marketing. $8^{\text {th }}$ edition. New York: Mc Graw Hill Inc.

Cummins, J. 1991. Promosi Penjualan.Alih bahasa Heryanto G. Cetakan Pertama. Jakarta: Bina Rupa Aksara.

Damanhuri, E. 2006. Jurnal Infrastruktur dan Lingkungan Binaan: Air, Sanitasi dan Udara Bersih Kebutuhan Dasar dalam Lingkungan Pemukiman. 2(2): 1-4
Ferrinadewa \& Darmawan. 2004. Konsep Marketing Mix. Edisi Pertama. Yogyakarta: Graha Ilmu.

Guiltinan, J. P., Paul \& Madden, T.J. 1997. Marketing Management: Strategies and Programs. $6^{\text {th }}$ edition, New York: McGraw-Hill

Kauko, T. 2006. What Makes a Location Attractive for the Housing Consumer? Preliminary Findings from Metropolitan Helsinki and Randstad Holland Using the Analytical Hierarchy Process. Journal of Housing and the Built Environment. 21. 159-176.

Kountur, R. 2007. Metodologi Penelitian untuk Penulisan Skripsi dan Tesis. Jakarta: Penerbit PPM.

Musthofa, B. 2008. Kamus Kependudukan. Yogyakarta: Panji Pustaka.

Prajayanti, A. 2013. BI Optimis Pertumbuhan Ekonomi Jatim Meningkat. (www.centroone.com/ news/2012/08/4v/bi-optimis-pertumbuhanekonomijatim-meningkat/, diakses 15 Januari 2013)

Primananda, A. 2010. Faktor-Faktor yang Mempengaruhi Konsumen dalam Membeli Rumah (Studi Kasus di Perumahan Bukit Semarang Baru, Semarang). Universitas Diponegoro http://eprints.undip.ac.id/23081/1/Skripsi_PDF.p df.

Properti Indonesia. Pebruari 2004. Penyempurnaan Kawasan Perumahan.

Rahardian. 2003. Manajemen Bisnis Properti. Jakarta: Bumi Aksara.

Ratnawati. 2002. Penyempurnaan Kawasan Perumahan. Majalah Properti Indonesia. p. 37.

Sanda, A. 2003. Perkembangan Perumahan RealEstate". Kompas, p. 9.

Schiffman, L. G. \& Kanuk, L. L. 2010.Consumer Behavior. $10^{\text {th }}$ ed. Upper Saddle River, New Jersey: Pearson Prentice Hall.

Sirgy, M.J., Grzeskowiak, S. \& Su, C. 2005. Explaining Housing Preference and Choice: The Role of Self-congruity and Functional Congruity. Journal of Housing and the Built Environment. 20.329-347.

Sugiyono. 2006. Metode Penelitian Bisnis. Bandung: CV Alfabeta

Tjiptono \& Afandi. 2006. Konsep Strategi Pemasaran. Yogyakarta: BPFE-UGM.

Wurtzebach \& Miles. 1994. Interior Desain.Sidney: Harper Collins Publishers.

Yahya, K. 2012. Permintaan Hunian di Kota Besar Terus Meningkat. Ekonomi Makro, Koran Jakarta Digital Edition (http://koranjakarta.com/ index.php/detail/view01/99448, diakses 31 Agustus 2012). 